\section{Światto i jego antynomie jako narzędzie narracyjne w architekturze}

\section{Light and its Antinomies as a Narrative Tool in Architecture}

Abstrakt

Mgła i pófmrok budzą wyoraźnię pisał Juhani Pallasmaa. XX i XXI wiek to czas postępującego zanieczyszczenia świetlnego Ciemnoś obs be formalnego stanowiacego o narracii znaczeniowej dzieła. Architektura eksploatuje zarówno światto jak i mrok, a interpretaci każdej z tych kategorii można dokonać przez odniesienie do jej przeciwieństwa. Autorka bada zastosowanie ciemności i pót mroku w architekturze, a takìe symbolike światta i cienia, zarówno jako środków sobie przeciwstawnych, jak i tworzacych wspólnie pełnię kompozycji.

\section{Abstract}

Juhani Pallasmaa wrote that the mist and twilight stimulate the imagination. The XX and XXI century is a time of constantly increasing light pollution. The darkness that is observed in nature is currently a state that cannot be encountered in the city. At the same time, creative activities that constitute themselves through experiments in lighting are being developed. The limiting of light currently fulfils the role of an intentionally used formal measure that defines the narration of the sense of a work. Architecture exploits both light and darkness, and the interpretation of both of these categories can be performed through referring to their opposite. The author analyses the use of total and partial darkness in architecture, as well as the symbolism of light and shadow, both as opposing measures, as well as those that mutually shape the fullness of a composition.

Stowa kluczowe: mrok, światto, symbolika, ekspresja, akcent, zanieczyszczenie świettne, narracja
Keywords: darkness, light, symbolism, expression, accent, light pollution, narration

\section{Wprowadzenie}

Cienie są czymś, z czym trzeba podjąć grę. W cieniu jest coś, co zawsze uchodzi naszej uwadze

Caravaggio nazywany jest malarzem światła, choć jego twórczość skąpana jest $\mathrm{w}$ ciemności. Jedno $\mathrm{z}$ wielu jego dzieł przedstawiających biblijne przypowieści to Wieczerza w Emaus - obraz z 1601 roku, powtórnie namalowany w 1606, w ciemniejszej, bardziej mrocznej manierze. Dojrzały już artysta rezygnuje z zabiegu rozproszonego światta i zastępuje go gwałtownym kontrastem między gęęboką ciemnością, a fragmentami mocno nasyconymi swiatłem, kluczowym dla interpretacji obrazu. Swiatło zostało zastosowane w znikomej ilości, a materią, dzięki której stanowi o metafizycznym wymiarze dzieła, jest otaczająca go ciemność, tak charakterystyczna dla narracji2 autora

W przestrzeni, światło, które ma znaczenie symboliczne potrzebuje tła, na którym może się zaprezentować. $W$ takim przypadku mrok stanowi materię, w której można wyrzeźbic

\section{Introduction}

Shadows are something that we should play with Within the shadow there is a/ways something that elude our attention.

Caravaggio is called a painter of light, even though works depicting biblical events is Supper at Emaus a paining from 1601, repainted again in 1606 in a dakke, more obscure manner. The mature artist abandoned the use of dispersed light and replaced it with a sharp contrast between the deep darknes and fragments that are heavily saturated with light, which are key to the painting's interpretation. Ligh that defines the metaphysical dimension of the work, is the darkness that surrounds it, so distinct of the author's ${ }^{2}$ narration ${ }^{3}$

In a space, light - possessing a symbolic meaning - requires a background on which it can present itself. In this case, the darkness constitutes the mathis works are steeped in darkness. One of his main
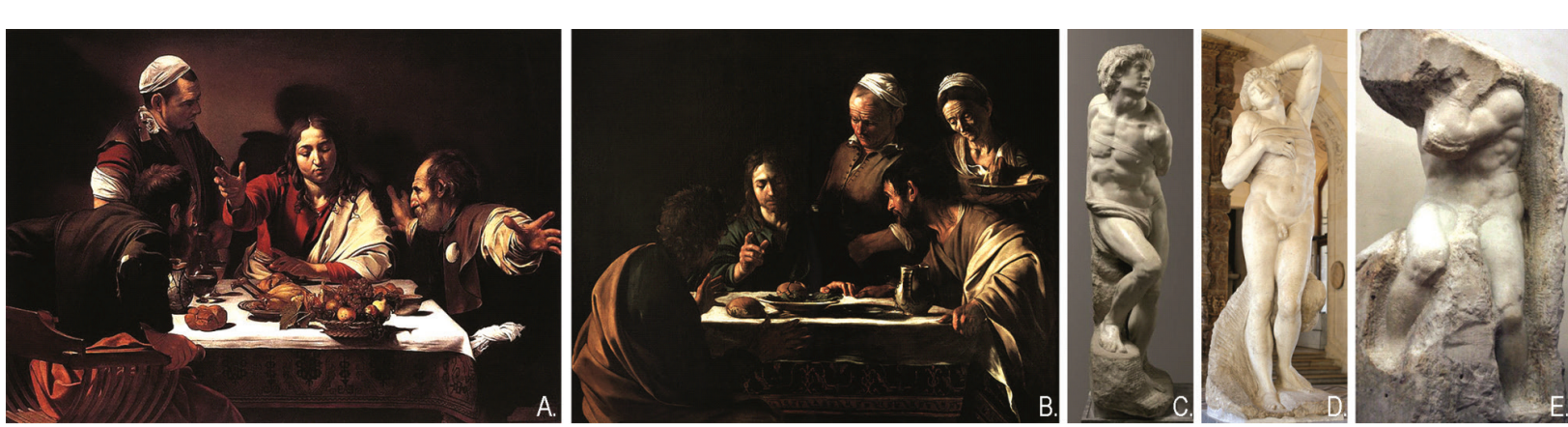

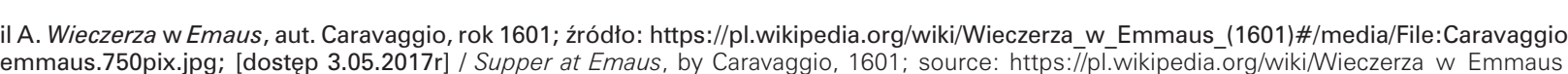

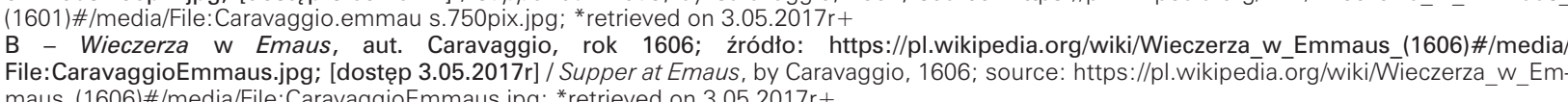

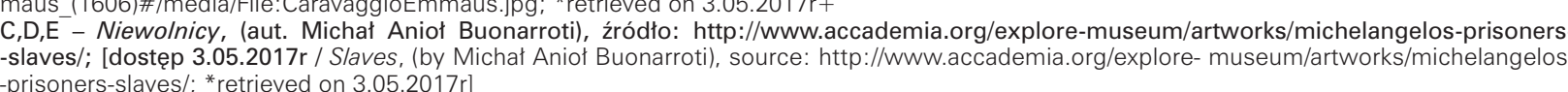

świattem odpowiednia kompozycje przestrzennego chiaroscuro ${ }^{4}$. Już Michał Anioł docenił wartość materiału, pozornie nieatrakcyjnego, stanowiącego negatyw jego własciwe twórczości. W serii rzeźb Niewolnicy pozostawił fragmenty szorstkiego, nieopracowanego kamienia, jako pełnoprawne fragmenty kompozycji. Podobną metodę zastosuja po nim inni wielcy twórcy, jak Auguste Rodin ${ }^{5}$.

Architektura to gra brył w świetle ${ }^{6}$, a cień jest niezbędny, by była ona kompletna. Swiatło i mrok to antynomie, które nie mają prawa bytu, gdy rozpatrywane są kazda z osobna. Konieczne jest pojęcie mroku, by określić światłość, i odwrotnie. Jakie znaczenie $\mathrm{w}$ odbiorze architektury mają zabiegi światłocieniowe? Jakie wartości nieformalne stanowią o charakterze i znaczeniu zastosowanych efektów? Autorka analizuje zastosowanie ciemności i półmroku w architekturze, a także symbolikę światta $i$ cienia na podstawie literatury $i$ badan własnych.

\section{Mrok jako rozwiazanie funkcjonaln}

świadomi korzyści, jakie niesie za sobą dostarczanie światta sw poączeniu z wiedza i możliwościami dziciejzego budow-

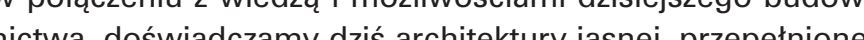

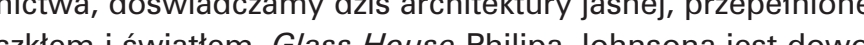
dem iswi ż dziek świtlu w duzej lości, mozina stwowo cich

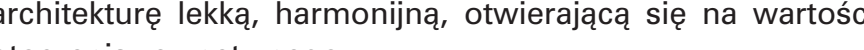

a pomieszczenia wymaga całkowitego (bądź tymczasowego) zaciemnienia jak laboratoria, ciemnie, sale knowe czy koncertowe. Szczelne pomieszczenia pozbawione swiatia tworzone są także w celach naukowych. Tak zwane komory deprywacyjne to pomieszczenia, gdzie w celach naukowych mozna doswiadczyc braku bodzcow zmysłowych. Panuje w nich całkowita ciemnosc, cisza, a także w niektorych mozilwe jest lewitowanie w cieczy, ktora zapewnia dezaktywację zmysłu dotyku. Czas spędzony w komorze deprywacyjnej moze doprowadzic do skrajnych stanow emocjonalnych jak euforia, niepokój, panika?. Dowodzi to, że do- ter in which one can use light to sculpt an approMichelangelo who acknowledged the val of the material - seemingly unattractive - that constituted the negative of his own work $\mathrm{In}$ his series of sculptures titled Slaves, he left fragments of raw, unworked stone as fully fledged composition fragments. A similar method would later be used by great artists like Auguste Rodin

Architecture is the learned game, correct and magnificent, of forms assembled in light ${ }^{6}$, and shadow is required for it to be complete. Light and darkness are antinomies, which cannot exist when discussed individually. A concept of darkness is required to define light and the other way around. What is the meaning of measures using light and formal values determine the charcture? What intance of the effects that have been used? The author analyses the use of $\mathrm{full}$ and partial darkness in architecture, as well as the symbolism of light and shadow, based on literature and original research.

2. Darkness as a functional solution

Aware of the benefits that the provision of light brings, combined with the knowledge and capabilities of modern construction, we are now experiencing an architecture that is bright, filled with glass and light. Philip Johnson's Glass House is proof of the fact that thanks to lange quantities of ight we can create an architecture that is light, harexternal surroundings.

However, there are situations in which a room's form of use requires complete (or temporary) darkness, such as laboratories, darkrooms, movie theatres or concert halls. Airtight rooms with no access to light are also built for scientific purposes. So-called deprivation chambers are rooms where scientifically analysed. They are places of com- 
świadczanie całkowitej deprywacji sensorycznej (w tym ciemności) kojarzy się negatywnie.

Dwudziesty wiek to czas światła. Wciąż rosnące zanieczyszczenie świetlne, sprawia, że zjawisko ciemności jest coraz rzadziej spotykane, a w mieście niemal zupełnie. Dzięki ciemności możliwa jest cała gama nowych form ekspresji w dziedzinie twórczości wizualnej. Współczesne muzea nieraz celowo rezygnuja z dostepu do naturalnego oświetlenia, które bywa nieprzewidywalne, a w przypadku zmiennych ekspozycii również oświetlenie musi sie zmieniać w sposób konpozycji, ny. Superposition (aut. Ryoji lkeda) jest przyktadem intowa

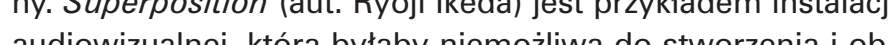
and and Mro (21.06 2015-9. 08 2015). Jedyie waens Why Micro przez człowieka jest w stanie stworzyć warunki odpowiednie dla funkcjonowania sztuki iluminacyjnej.

\section{Mrok jako zabieg formalny}

Przedstawione wnętrza wykorzystują ciemność i półmrok w charakterze niezbędnym dla ich funkcji. Są jednak i takie, w których ciemność pełni rolę elementu twórczego. Takie przykłady możemy zauwazyc przede wszystkim w architekturze, która stwarza możliwośc przywiązania więcej uwag treści i formie dzieła, niż jego funkcji. Wtedy efekt światłocieniowy staje się elementem stanowiącym o narracji znaczeniowej dzieła.

Mrok może być elementem kompozycyjnym w przestrzeni architektonicznej. Nie sposób jednak interpretować jego znaczenia bez precyzyjnego określenia kontekstu kulturowego, w jakim się znajduje. [...] Nie istnieje nic takiego jak czysta percepcja. Każde zmystowe postrzeganie przechodzi w nieunikniony sposób przez wielorakie filtry kultury iznaczenia: pojęcia i struktury dostarczane przez język oraz znaczenia wpojone przez kultures. W kulturze europejskiej światło jest elementem nacechowanym pozytywnie, $z$ wieloma konotacjami znaczeniowymi Może wiqzać sie z takimi wartościami jak dobro, medrość, to Opatrzność, nadzieja, cel, przebaczenie etc. ${ }^{9}$ Sa to wartości, to wra spra dencjl. Mrk, zo koci-

列 chitektonicznej jest droga pokonywana w starożytnej świątyni egipskiej. Sciežka prowadzila przez kolejno coraz mniejsze i ciemniejsze pomieszczenia, az do oftarza-miejsca całkowicie pozbawionego światla dziennego. Swiatto nie zawsze musi być tożsame z symboliką boskiej siły. Może być zastapione ciemnoscią, poglębiającą poczucie intymności, wyłączności czy bojaźni. Pozbawienie danej przestrzeni okien może byc też wyrazem opieki nad zawartością i chęci "schowania” jej głęboko w bezpiecznym miejscu'10.

Bazylika Mariacka w Neviges - Gottfried Böhm, Werner Finke, 1968

Bazylika Mariacka w niewielkim miasteczku Nadrenii - Neviges, zawdzięcza swoje powstanie licznym pielgrzymkom od- plete darkness and silence, with some featuring levitation while being submerged in a liquid which deactivates the sense of touch. Time spent with a deprivation chamber can lead to extreme emoproves that experiencing total sensory deprivation (including darkness) has negative associations. The twenty first century was a time of light. The still increasing light pollution makes the phenomenon of darkness less and less encountered, and it is almost impossible to experience within a city. expression are possible in the visual arts. Modern museums sometimes deliberately eschew natura lighting, which is sometimes unpredictable, and in the case of changing exhibitions, lighting mus change in a controllable manner. Superposition (by Ryoji lkeda) is an example of an audiovisual instalation which would be impossible to create and Art and Media Technology in Karlsruhe, during the Micro macro exhibition (21.06.2015-09.08.2015). Only an interior built by man is capable of producing proper conditions for the functioning of illuminative art.

3. Darkness as a formal measure

The interiors that have been presented use total 作 of use requires. However there are also those in which darkness plays the part of a creative elethe type of archiples can chiefly be observed in the type of architecture that provides the oppora work than its function. Then the effect of light and shade becomes an element that defines the narrative of the sense of a work.

Darkness can be an element of composition within an architectural space. However, we are unable to therpret its meaning whout precisely determining the cultural context in which it is placed. [...] Somery perception goes invaribly through all manners of filters of culture and meaning: the notions and structures provided to us by language and meanings ingrained in us by culture. In European culture, light is an element with positive qualities, with numerous connotations in terms of meaning. It can dom, grace Providence hope a goal forgiv, wis-

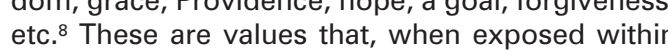
a symbolic space, cause the interior under discussion to elicit an impression of transcendence. Darkness, on the other hand, can be interpreted as it opelle, not only hin terms of form, but sense as One of the examples of the meaning of light withthrough hitectural composition are paths leading through successively smaller and darker rooms, al the way to an altar - a place completely deprived of with the Light does not always need to be equated with the symbolism of divine power. It can be retimacy, exclusiveness or fear. Removing windows from a given space can also be an expression of care over its contents and a willingness to "hide" it deep within a safe place
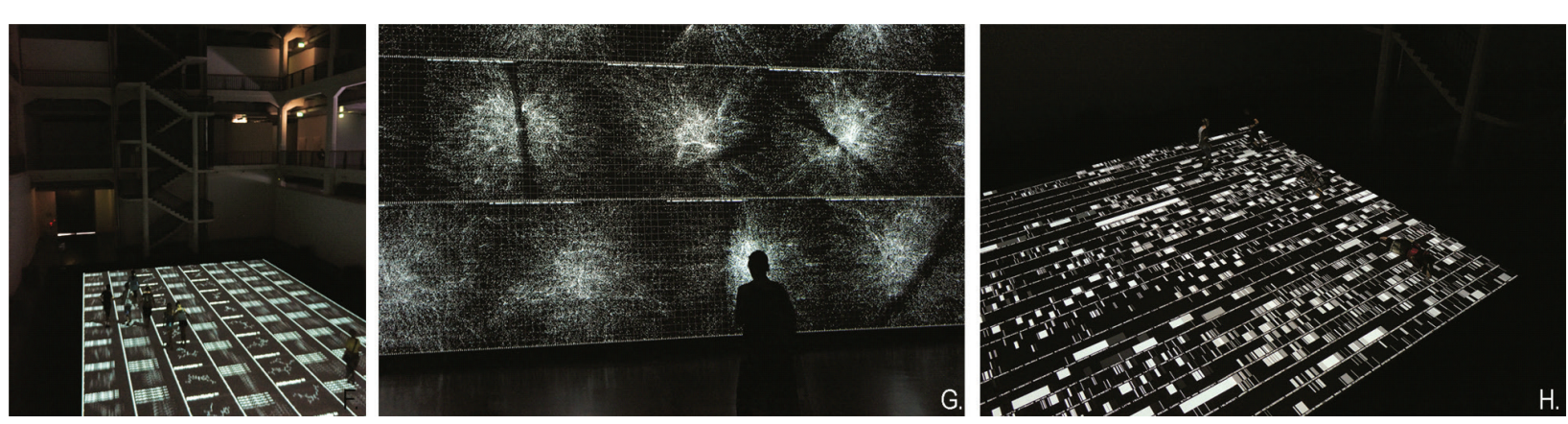

il. F,G,H. Superposition, aut. Ryoji lkeda, fot. Beata Malinowska-Petelenz / Sup

wiedzającym cudowny obraz Niepokalanego Poczęcia z 1661 roku, który znajdował się w niewielkim kościele św. Anny ${ }^{11}$ Forma zdecydowanie dominuje w sylwecie miasteczka zarówno skalą, jak i ekspresja. Betonowy, "skalisty" dach nawiązuje do formy architektury regionalnej Neviges. Do kościoła prowadzi szeroka, pielgrzymkowa droga, z której wchodzimy do wnętrza pozbawionego osiowości, złożonego z wielu przestrzeni'2.

Lita, pozbawiona okien struktura miała stworzyć symbolike i wartość ",namiotu świątynnego". Możliwe są także inne podobieństwa - do „,biblijnej skaly", ,,sztucznego wzgórza", , groty" wraz z wszystkimi przymiotami odnoszacymi sie do kultu kamienia jako pierwotnej intuicji symboliki chrześcijańskiej'is. Obserwator znajduje się w ogromnym wnętrzu, całym w surowym betonie. W pierwszej chwili można odczuwać wrażenie przebywania w przestrzeni publicznej - pod wielkim namiotem goszczącym tłum pielgrzymów, na ulicznej kostce brukowej, pod uliczną latanią. Surowy beton, niepokojące, ukosnn płaszczyzny sklepienia i zdawkowe, nieregularne oświetlenie przywodza na mysl jaskinie i wprowadzają charakter pierwotnego skupienia. Projekt gmachu przygotowany jest w sposób zapewniający wieczny połmrok - otwory okienne występuja sporadycznie, a światło, które z nich pochodzi, tłumione jest przez rozrzeźbioną strukturę ścian wewnętrznych i służy raczej eksponowaniu nakładających się na siebie - pod różnym katami - płaszczyzn, niż rzeczywistemu oświetleniu wnetrza. Matowy, szorstki materiał betonu dodatkowo pochłania promienie słoneczne, nie odbijając ich.

Światto potraktowane w sposób intencjonalnie zdawkowy Sich zdawkowy w ty wo widac w tym wetrzu wprowadza charakter mistyczny. Nie wid sie wobne wary wa te a dy miczny swiena wa częsciow zabudowanch od strony whętra. W samych galeriach - przestrzeni "odgrodzonej" od oltarza - Wlaściwego miejsca celebracji panuje swiatlośc. Jednak to światlo do reszty wnętrza wpada juz $w$ formie szczątkowej. Nie oświetla go, ale intryguje przeswitującymi z galerii promieniami ukrywając źrodło światla. Trzecim rodzajem zabiegu wykorzystującego swiatio dzienne we wnętrzu, są witraże, autorstwa samego Gotfrieda Böhna, kocre także chronią wnętrze przed oświetleniem bezpośrednim, za pomocą koloru. Można wyróżnić dwa charakterystyczne witraże - w głównym wnę-
St. Mary's Basilica in Neviges - Gottfried Böhm, Werner Finke, 1968

The St. Mary's Basilica in Neviges, a small town in Rheinland - owes its construction to nume1661 , which was located in the small church of $\mathrm{St}$ skyline of the town both due to its scale, as well as its expression. The concrete, "rocky" roof references the form of the regional architecture of Neviges. A wide path for pilgrims leads to the church, symmetry, we enter into an interior devoid of axha The solid, windowless structure was to create the rock", the "artificial hill", the "grotto" along with all the qualitities that refer to the cult of stone as the Trimal intulion of Christian symbolism terior, all of it in raw concrete. At first one can get derneath a large tent housing a crowd of pilgrims concrete, the unsettling diagonal surfaces of the ceiling and the laconic, irregular lighting bring to focus. The design of the building has been devel oped in a manner that provides an eternal partial darkness - the window openings are sporadic and the light that comes through them is dimmed by the rich structure of the internal walls and serves to expose the overlapping surfaces - under various rior. The matte, rough texture of the concrete additionally absorbs solar rays without reflecting them. Light is treated in an intentionally laconic manner in this interior, introducing a mystical character. We do not see direct light. Right near the vault there are small openings which cast a little bit of that have been placed near the heavy, concrete galleries, partially built up from the inside. In the galleries themselves - in the space "fenced off" from the altar - the proper place of celebration - is where brightness reigns. However, this light enters the rest of the interior in a partial form. It does not that go through the galleries, hiding the source of the light. The third type of measure that makes use of daylight within the interior are stained glas ous pilgrimages that come to visit the miracuAnna ${ }^{10}$. The form confidently dominates within the symbolism and value of the "temple tent". Other similarities are also possible - to the "biblical on street cobblestone, near a street lamp. The raw light upon it, providing a dynamic interplay of light 


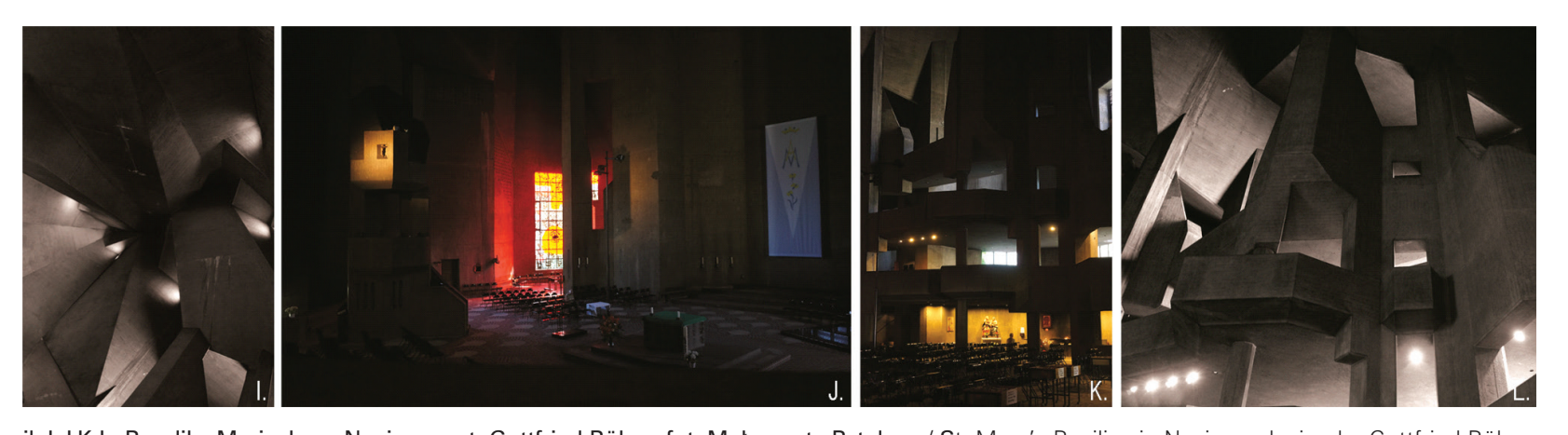

il. I,J,K,L. Bazylika Mariacka w

Neviges, aut. Gottfried Böhm, fot. Małgorzata Pe

Neviges, design by Gottried Böhm

trzu - przedstawiający różę, której światło padając na otaczający beton, nadaje mu intrygujący ciemnoczerwony odcień (symbolizujący zarówno miłosc, jak i cierpienie). Drugi witraż moźna zauwazycy drodze do dolnego kościola- przedstawia on w swobodny sposob figurę węza deplanego przez ludzkie stopy. Oba nawiązują do symboliki maryjnej, której ikonie dedykowana jest katedra.

Te zabiegi sugeruja, że autor intencjonalnie stronił od bezpośredniego oświetlenia wnętrza, dzięki czemu uzyskał efekt przestrzeni mistycznej, skąpanej w sfumato ${ }^{14}$ sprzyjającemu skupieniu. Mgła i pófmrok budzą wyobraźnię pisał Juhani Pallasmaa, a Gottfried Böhm podobną zasadę wprowadza w życie traktując półmrok jako wszechobecną masę, w której negatywowo "rzeźbi" świattem

Rasmussen podobne zabiegi komentuje w przypadku wnętrza Kaplicy w Ronchamp Le Corbusiera: Wnętrze budzi silne emocje; opiera się na pełnej cieni mroczności pośredniego oświetlenia, w którym forma jest tylko niejasno zarysowana ${ }^{15}$. Podsumowuje zależność między światłocieniem we wnętrzu a stanem emocjonalnym odbiorcy. Jednocześnie, podkreślając oszczędne użycie światła, podsumowuje to jako wyraz najwyższego kunsztu Corbusiera: Autor w dobitny sposób pokazuje, jakim cudownym środkiem wyrazu jest światto i sposób jego dystrybucji16.

Kolejnym przykładem architektury sakralnej, która zdawkowo wykorzystuje światło dzienne jest Kaplica Brata Klausa Petera Zumthora w Mechernich-Wachendorf, której wysokie, ciemne wnętrze eksponuje zdawkowe, naturalne światto padające z góry. Po uchyleniu drzwi we wnętrzu ogarnia nas dające z góry. Po uchyleniu drzwi we wnętrzu ogarnia nas
pótmrok, subtelne odblaski światta potyskują na posadzce zolowiu i cyny jak na pomarszczonych wiatrem falach jezolowiu
ziora

Muzeum Żydowskie w Berlinie - Daniel Libeskind, 1998 Muzeum Żydowskie w Berlinie jest kolejnym przykładem architektury pełnej symboli. Oprócz funkcji muzeum, jest pomnikiem pamięci berlińskiej społeczności żydowskiej. Po raz kolejny, to nie funkcja (choć wciąż istotna) jako pierwsza zwraca uwage odbiorcy, ale forma i wrażenia, jakie wywołuje. Przykład ten wpisuje się w trend projektowania muzeów będących nie tylko them dla eksponatów i informacji, ale takze przestrzenią narracyjną, której celem jest wywołanie konkretnych emocji (np. Muzeum Historii Żydów Polskich POLIN, aut. Lahdelma \& Mahwindows, designed by Gottfried Böhm himself,
which also protect the interior from direct light by glass windows - one in the main interior - depicting a rose, whose light, when falling on the surrounding concrete, gives it an intriguing dark red the way to the lower church - it loosely depicts the figure of a snake being trampled by human feet. Both refer to the symbolism of the cult of Mary, to whose icon the cathedral is dedicated.

These measures suggest that the author intentioncal space, bathed in a sfumato' 13 that is a mystto maintaining focus. Juhani Pallasmaa wrote that mist and twilight awaken the imagination and Gottfried Böhm implemented a similar principle, treating darkness as an ever-present mass, from which he negatively "sculpts" with light champ: The interior elicits strong emotions; it is based on a darkness of indirect light, full of shade, in which form is only vaguely outlined ${ }^{14}$. He summarised the dependencies between light and shadow within an interior and the emotional state of the observer. At the same time, highlighting the sparing use of light, he sums it up as an expression of Le Corlight - and the manner of its distribution - is ${ }^{15}$. Another example of religious architecture which sparingly uses daylight is the Bruder Klaus chapel by Peter Zumthor in Mechernich-Wachendorf, whose tall, dark interior is exposed by the austere, ly opening the doors, we are engulfed in partia
darkness within the interior, the subtle reflections of light glow on a floor of lead and tin like on the waves of lake, rippled by wind'

The Jewish Museum in Berlin - Daniel Libeskind

The Jewish Museum in Berlin is another example from the function of a museum, it is a monument to the memory of Berlin's Jewish community. Once again, it is not the form of use (although still important) that first captures our attention, but the form using colour. We can identify two distinct stained The second symed gos bove love sufferingl. ally refrained from directly illuminating the interio

Rasmussen comments on similar measures in the shows just how wonderful a means of expression natural light flowing in from above. After sligh-
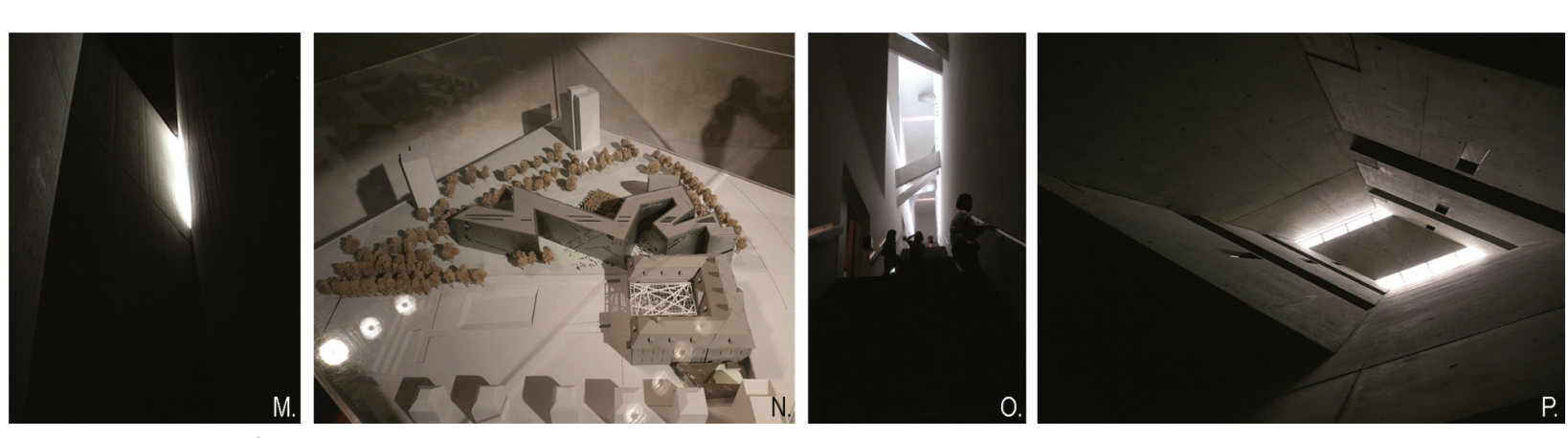

il. M,N,O,P-Muze
by Marcin Petelenz

lamäki+ Kuryłowicz \& Associates, Warszawa 2013). W przypadku tego typu dziet, wiele emocij zostaje wywołanych dzięki ekspresyjnym efektom światłocieniowym, utrzymując dramatyzm towarzyszący całej twórczości Daniela Libeskinda.

Ukończony w 1998 budynek jest częścią Muzeum Historycznego Miasta Berlina, którego siedziba znajduje się w barokowym pałacu Collegienhaus - jedynej pozostałości po zbombardowanej podczas II wojny światowej historycznej dzielnicy Friedrichstadt18. Forma budynku nawiązuje do zdekonstruowanej gwiazdy Dawida, a liczne krzywizny formy wyznaczaja kierunki w strony ważnych miejsc w kulturze żydowskiej, na planie Berlina.

Zwiedzanie muzeum zaplanowane jest w formie drogi, która trzeba przemierzyc według scenariusza. Sciezka rozpoczyna się w barokowym pałacu i prowadzi gości do nowej części a zaraz potem pod ziemię. Klatka schodowa, którą schodzimy ponizej poziomu parteru jest skapo oświetlona - tylko na tyle, by zapewnić minimum funkcjonowania. Wszystkie płaszczyzny są w kolorze głębokiej czerni i giną w mroku. Dzięki temu już na samym początku zwiedzania obserwato ma intuicyjne poczucie uwięzienia i przestrzeni, w której kryje sie przemoc i napiecie Przestrzen ta prowadzi do kolejnej cześci muzeum, pod ziemia gdzie panuje oświetlenie szjuczne, w formie nieprzerwanych wsteg biatego śmiatta w sufie. wzdtuz trzech osi: Osi Ciagtości, Osi Emigracii Osi Hocie, wzd for noch osi: Osi Ciaglosci Osi Emig acli Osi Holokaustu. Podziemny pasaz laczy stary i nowy budynek, ale skiego żyów w Berlinie, wyprowadza obserwato z zownosc żydów w Berling, wyprowadza obserwatora z powrotem na wyższa kondygnacje monumentalnymi schodami, konczącymi dugi korytarz. Wraz ze Wznoszeniem się schodów gwaltowanie wzrasta losc swiatla dziennego. Przestzen nad schodami ponownie osiąga pełną wysokość budynku, jednak dzięki światłości stanowi efekt negatywu w stosunku do przestrzeni, która sprowadza w dól.

Oś Emigracji wyprowadza na zewnątrz budynku, na plac zabudowany czterdziestoma dziewięcioma betonowymi filarami, w których posadzono drzewa. Małe odległości między filarami, sprawiają, że panuje pomiędzy nimi półmrok, a nachylona posadzka budzi poczucie zdezorientowania i narastaącego niepokoju. Plac jest zapadnięty poniżej terenu, co dodatkowo zaciemnia przestrzeń ekspozycji i potęguje poczucie izolacji. Jego otwarcie na świat jest jedynie pozorne. and the impressions that it inspires. This example is part of a trend of designing museums which are nation a but are around for their exhibits and inforMuseum of the History of Polish Jews by Lahdelm for the in the case of hisse types of works, much shade effects, which support the dramatic tension that accompanies Daniel Libeskind's entire ouvré. The building, which was built in 1998, is a part of the Berlin History Museum, whose headquarters is located in the Baroque Collegienhaus palace he only remnant of the historical district of FrieWorld Wart 1 . The form of the building is a Secone to the deconstructed star of David, and its numerare important in Jewish culture on Berlin's plan. Touring the museum is planned out in the form of a pathway, which needs to be travelled in accordand, at the same time, underground. The staicase that we use to go below ground level is barely lit - only as much as to provide a modicum of functionality. All the surfaces, jet black in colour, disappear in the darkness. It is due to this that, already at the start of the tour, the observer has a feeling violence and tension are thesent a space in which us to an which is dominated by artificial lighting in the form of continuous lines of white light on the ceiling. along three axes: the Axis of Continuity, the Axis of Emigration and the Axis of the Holocaust. The underground passage connects the old and the new builling, as well as, symbolically, the history of longest the Axis of Continuity, which represents the presence of Jews in Berlin - leads the observer back to the highest level through a monument staircase, which is at the end of a long corridor. As the stairs rise, so does the amount of daylight rapidreaches the full height of the buildings, however The Axis of Emigration leads us outside the building, to a space built up with forty nine concrete is to stimulate particular emotions (e.g. the POLIN 2013). In the case of these types of works, much ous curvatures point in the direction of places that ance with a script. The pathway starts in a Baroque Iy increases. The space above the stairs once again relation to the space, which leads downwards. 
Na końcu prześwietlonego korytarza Osi Holokaustu obserwator napotyka proste, czarne drzwi Wieży Holokaustu. Wieża ta, to wysokie pomieszczenie o nieregularnym kształcie. W tym miejscu poczucie uwięzienia w niezrozumiałej przestrzeni narasta. Pomieszczenie skąpane w ciemności, oświetIone jest jedynie drobnym otworem u szczytu. Nie dostarcza on niemal światła do poziomu, gdzie znajduje sie obserwator. Sprawia wrażenie światta niewystarczającego, którego brakuje i które jest niedostepnne. To przestrzén, która za pomoca je i któné jest niedostén ś. To przestren, kóra za pomoca w putapce, whtórej Wuzeum jest kronika dwóch Muzeun jest konikg dwoch tysiecy la histonir niemieckich

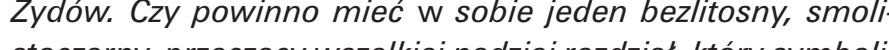
stoczarny, przeczacy wszelliej nadziei rozdzial, ktory symbolizowalby wszystko, cozostato nstacon podzzas Holokaustu? Konty uacja pomysu wyjok proje strzeni są czarne wieze, zwane przez autora Pustkami (The Voids). To kolejne pomieszczenia - studnie, skąpo oswietlone jedynie od góry, co przy tej wysokości sprawia, ze światło dzienne nieomal nie dociera do podłogi. Ten niepokojący półmrok i milcząca przestrzeń to jedyna cecha charakterystyczna The Voids - pozbawione są innych funkcji. Symbolizuja napięcie w stosunkach niemiecko-żydowskich, które autor eksponuje. Symbolizują także trudne przestrzenie $w$ dialogu o Holokauście - do pięciu z sześciu Pustek nie można wejsc, a jedynie obserowac wnętrze przez otwory w ścianach przypominające skaryfikacje. Główna wieża - The Void of Memory-Wieża Pamięci - to skąpane w półmroku przejście, którego posadzka pokryta jest stalowymi rzeźbami, przedstawiającymi uproszczone, powykrzywiane ludzkie oblicza. Odwiedzający pod koniec zwiedzania, by przejść przez The Void of Memory zmuszony jest kroczyć po "twarzach” i przeżyć pewnego rodzaju katharsis.

Daniel Libeskind posługuje sie ciemnościa w przestrzeniach traumatyzujących, o dużym ładunku emocjonalnym. W tym przypadku mrok przywodzi na myś cierpienie, bezradnośc i izolaci. W prze kralnych gdzie pót ści, w Muzeum Żydow sci, w Muzeum żydow

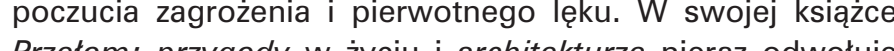
Przelom : przygody w żciu i architekurze nieraz odwołuje

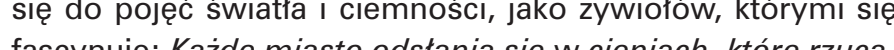
fascynue: Kazde miasto odstania sie w cienoch, ktore rzuca ja jego budynki. Pokazuje swà prawdziwą istotę, swą duszę. swiatto to symbor boskosci, Swiatro jest miarą wszystkiego. Jest absolutne, nieodwracalne, skończone, matematyczne, wieczne ${ }^{2}$

Narracja w miejscach pamięci związanych z Holokaustem, [...], posiada wiele cech wspólnych dotyczących zagadnień eschatologicznych -życia i śmierci ofiar ${ }^{22}$. Liczne przykłady architektury upamiętniającej Holocaust sięgają po zabiegi światłocieniowe, by w sposób bezcielesny dokonać syntezy
narracji cierpienia w przestrzeni, np. Instytut Pamięci Męczenników i Bohaterow Holocaustu Yad Vashem (Moshe Safdie, Jerozolima, 2005), Muzeum Walki i Męczeństwa w Palmirach (Sz. Wroński, W.Conder, Palmiry, 2011), POLIN czy Muzeum Powstania Warszawskiego w Warszawie. pillars in which trees have been planted. The smal distances betw partial darkness, and the inclined floor produces a feeling of disorientation and increasing anxie-
ty. The space is recessed to below ground leve which additionally darkens the exhibition leve and strengthens the feeling of isolation. It only seemingly opens up to the world.

end the brightly lit corridor of the Axis of the Holocaust, the observer encounters the simple black doors of the Holocaust Tower. This tower is ing of being imprisoned in an incomprehensibse spaces strengthens. The room, bathed in darkness, is lit only with a small opening at the top. Its light practically does not reach the level on which an observer is standing. This makes it feel like a light that is insufficient, of which there is a lack, and which is haccessible. This space, which, with the help of prisoned in a trap, in which the scale of an individual appears to mean nothing.

The museum is a chronicle of the two thousand years of the history of the German Jews. Should it have in it a single, merciless, pitch black chapter that goes against all hope, one that would symbol-
ise all that has been lost during the Holocast? The continuation of the idea of a tall, dark and crushing space are the black towers, which the author called The Voids. These are additional rooms - wells, barely lit solely from the top, which, considering the height, causes daylight to barely reach the floor. This disturbing darkness and the silen they serve no other purpose. They symbolise the tension in the relations between the Germans and the Jews, which the author exposes. They also symbolise the difficult spaces in the dialogue about the Holocaust - five of the six Voids cannot be entered their interior can only be observed by openings in er - the Void of Memory - is a passage bathed in partial darkness, its floor covered with steel sculptures depicting simplified, twisted human faces. The visitor, towards the end of the tour, is forced to step on these "faces" in order to cross the Void of Memory and experience a sort of catharsis.

Daniel Libeskind uses darkness in traumatising the darkness evokes suffering, helplessness and isolation. In contrast to the religious examples mentioned earlier, where partial darkness facilitates an atmosphere of focus and dignity, in the Jewish Museum it was used in order to deepen the feeling of danger and primal fear. In his book Przetom: przy cepts of light and darkness numerous times, seein them as elements that fascinate him: Every city uncovers itself in the shadows cast by its buildings. It shows its true essence, its soul. Light is a symbol of divinity, light is the measure of everything. It is absolute, ireversible, finite, mathematic, eternalis. Narration in places of memory associated with regarding eschatological subjects - the life and death of the victims ${ }^{21}$. Numerous examples of architecture that commemorate the Holocaust make use of measures featuring light and shadow, i

\section{PODSUMOWANIE}

Arnold Berleant okresla doswiadczenie estetyczne, jako sumę dwóch aspektów: aspektu zmysłowego, ktory jest pierwotny, a także doświadczenie znaczeń, które jest juz uzależnione od szeregu zmiennych, jak choćby konteks kulturowy czy tożsamość doświadczającego ${ }^{2}$.

Aspekt zmysłowy w przypadku doświadczania pótmroku jest w każdym przypadku podobny, zależy od formy i nasilenia wrażenia. Gdy zmyst wzroku zostaje ograniczony, pozostałe zmysty wyostrzaja sie. To doświadczenie znaczeń - przypisane do charakteru architektury i kontekstu, w jakim celu powstała - sp raw ze w przytoczonych przyktadach emocje balonsuia na granicy skrajnósi. W jednym przypadku znajdujemy ie w śmiatyni, a poczucie bezpieczenstwa sprawia í mrok wzmaga nasze zaintygowaie, ale i um

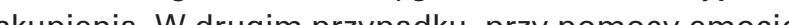

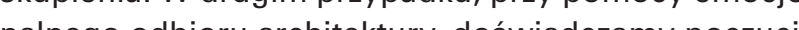

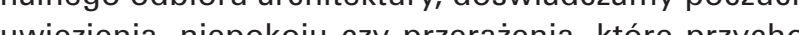
dza nam na myśl, gdy "dotykamy" pełnej cierpienia historii.

Efekty światłocieniowe pomagają w sposób niemateria hy i subtelny aranżować przestrzeń, a także nadawać jej charakter. Sposób ich zastosowania, wraz z konotacjam kulturowymi i kontekstem miejsca wspóttworzą narracje dzieła.

PRZYPISY:

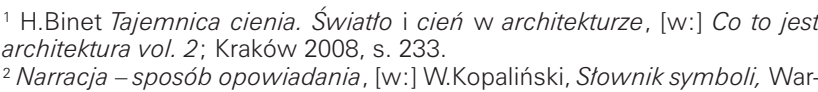
[...] ilekroc pęazzlem machnąt, wyrastat jakiś rys ciekawy, lato się wiel

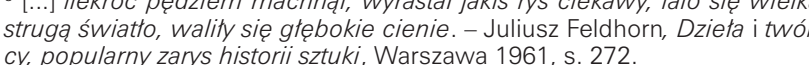

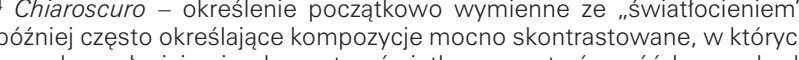

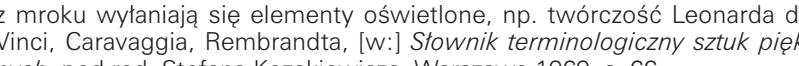
nych, pod.red. Stefana Kozakiewicza, Warszawa 1969, s. 66 .
5 Miekko wytaniajia się 2 kamienia pewne partie, potrzebne do uzskanti

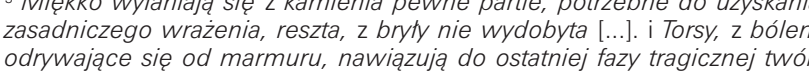

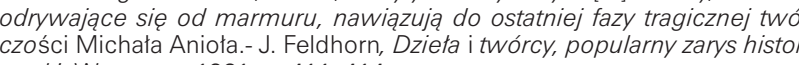

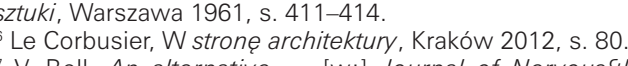

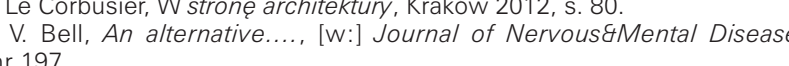
A. Berleant, Wraziliwość i zmysty - estetyczzna przemiana świata cztowieka,
Kraków 2010, s. 40 .

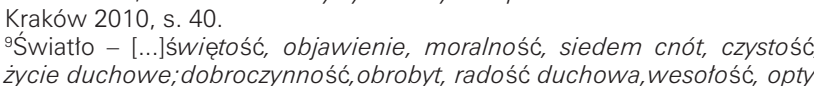

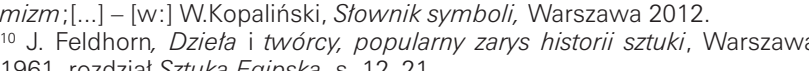
"dzisiejszy kościót parafialaln - pw. Niepokalanego Poczęcia

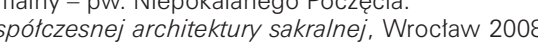
${ }_{3}$ M.Charciarek, Zwiazki idei i materii w architekturze betonowej, Krakón ${ }_{4}^{2015}$ S. S. 14r. prydymienie (przzp. Aut.); modelunek malarski miekki, o tagod

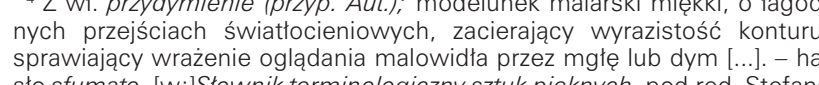

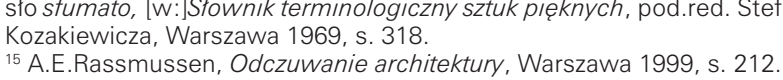

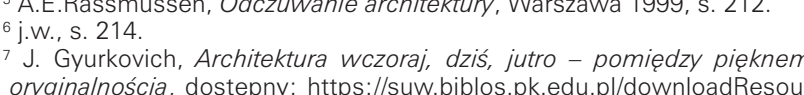
17. J. Gyurkovich, Architektura wczoraj, dzis, jutro - pomiedzy pieknem
i oryginalnoscia, dostepny: https://suw, biblos. pr.edu.pl/downloadResour
ceegrmld $=189832$, data dostępu 03.04.2017. order to formlessly perform a synthesis of the narration of suffering within a space, e.g. the Yad Vashem Martyrs and Heroes Remembrance Authority building, the PalmPalmiry, 2011), POLIN or the Warsaw Uprising Museer, Uprising Museum

4. CONCLUSION

Arnold Berleant defines an aesthetic experience as the sense who aspects. sensibility, which is primal, and the the cultural context or the identity of the person having the experience ${ }^{2}$

Sensibility, in the case of experiencing partial darkness, is always similar, depending on the form and intensity of the impression. When the sense of sight becomes limited, the to maining senses become sharper. The sense - ascribed was built - causes the emotions to balance on the edge of the extreme in the aforementioned cases. In one example we are in a temple and the feeling of security makes the darkness increase our feeling of being intrigued, as well as our ability to focus. In the second example, with the help of an emotional perception of architecture, we experience come to mind when we "touch" this history of suffering Effects of light and shade allow us to intangibly and subtly arrange a space, as well as bestow it with a character. The manner of their use, along with cultural connotations and the context of the space, co-create the narrative of a work.

ENDNOTES:

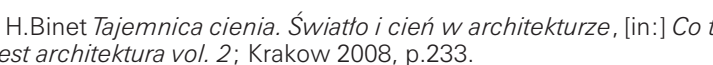
[1...] each time he made a stroke of the brush, sor

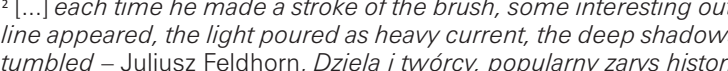

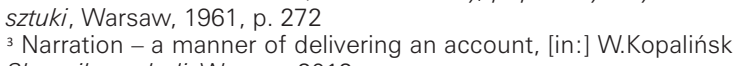
Slownik symboli, Warsaw 2012 .
"Chiaroscuro - a term initially ysed interchangeably with light and shadow, later often describing a highly contrasting composition,
in which lit elements emerge from the darkness, e. . the works of logiczny stuk pieknych,
icz. Warsaw 1969, p. 6 .

Sottly do certain parts emerge from the stone, those needed to
achieve the fundamental impression, the remainder, untaken from the stone ..... And the torsos, painfully stripping from the marble,
refer to the tinal tragic phase of the work of Michelangelo- J Feldhorn, Dzieta i twórcy, popularny zarys historii sztuki, Warsaw 1961. p. Le Corbusier, W strone architektury, Krakow 2012, p. 80
'V. Bell, An alternative..., [in:] Journal of Nervous \& Mental Disease, P. 197. ${ }^{2}$. Berleant. Wrażliwość $i$ zmysty - estetyczna przemiana świata "Light-I... holiness, revelation, morality, the seven virtues, purity,
spiritual life, charity, prosperity, spiritual joy, merriment, optimism, spiritual life, charity, prosperity, spiritual joy, merriment, optimism
[...]- [in: W. Kopalinski, Stownik symboli, Warsaw 2012.2. ${ }_{10} 0$ J. Feldhorn, Dzietai i twórcy, popularny zarys historii sztuki, War saw 1961, chapter Stztuka Egipska, p. $12-21$.
11 the current parish church - of Immaculate Conception. ${ }^{12} \mathrm{C}$. Was, Antynomie wspótczesnej architektury sakralnej, Wroctaw ${ }_{13} \mathrm{M}$. Charciarek. From Italian, 148 . in painting, with gentle transitions between light and shadow, blu-
ring the crispness of the contour, giving the impression of looking at a painting through mist or smoke [...] - sfumato, lin:] Stownik
terminologiczny sztuk pieknych, under the editorship of Stefan Ko

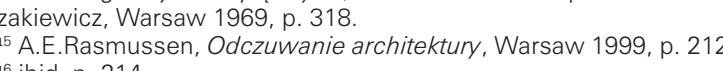


18 M.Gyurkovich, Współczesne muzeum w strukturze miasta, Kraków 2007, s.68-70.

${ }^{19}$ E.Węcławowicz-Gyurkovich, Architektura najnowsza w historycznym środowisku miast europejskich, Kraków 2013, s.179.

20 D.Libeskind, Przetom: Przygody w życiu i architekturze, Warszawa 2008 , s. 48 .

21 j.W.

22 A.M.Wierzbicka, Architektura jako narracja znaczeniowa, Warszawa 2013, s. 118

${ }^{23}$ A.Berleant, Wrażliwość i zmysty - estetyczna przemiana świata człowieka, Kraków 2010, s. 42.

\section{LITERATURA:}

[1] Bartnicka Małgorzata, Magia cienia w zabawie z architektura Czasopismo Techniczne, 9-A, 2015, dostepny online, 03.04.2017.

[2] Berleant Arnold, Wrażliwość i zmysły - estetyczna przemiana świata człowieka, Kraków, Polskie Towarzystwo Estetyczne, 2010, ISBN 97883-242-1663-5.

[3] Binet Hélène, Tajemnica cienia. Światło i cień w architekturze, [w:] Co to jest architektura vol. 2; Kraków, Manggha, 2008, ISBN 978-83-924407-8-9.

[4] Charciarek Marcin, Zwiazki idei i materii w architekturze betonowej, Kraków, Politechnika Krakowska im. Tadeusza Kościuszki,2015, ISSN 0860-097X.

[5] Feldhorn Juliusz, Dzieła i twórcy, popularny zarys historii sztuki, Warszawa, Wiedza Powszechna, 1961.

[6] Gyurkovich Jacek, Architektura wczoraj, dziś, jutro - pomiędzy pięknem i oryginalnością, dostępny https://suw.biblos.pk.edu.pl/ downloadResourcegmld=189832, data dostepu 03.04.2017.

[7] Gyurkovich Mateusz, Wspótczesne muzeum w strukturze miasta, Kraków, Politehcnika Krakowska im. Tadeusza Kościuszki, 2007, ISSN 0860 - 097X

[8] Le Corbusier, W strone architektury, Kraków, Centrum Architektury, 2012, ISBN 978-83-934574-9-6.

[9] Libeskind Daniel, Przełom: Przygody w życiu i architekturze, Warszawa, Wydawnictwo Naukowo-Techniczne, 2008, ISBN 97883-204-3474-3.

[10] Pallasmaa Juhani, Oczy skóry - Architektura i zmysty, Kraków, Instytut architektury, 2012, ISBN 978-83-63786-01-4

11] Rassmussen Steen Eiler, Odczuwanie architektury, Warszawa, Wydawnictwo Murator, 1999, ISBN 83-904692-9-4.

[12] Słownik terminologiczny sztuk pięknych, pod.red. Stefena Kozakiewicza, Warszawa, PWN, 1969.

13] Was Cezary, Antynomie wspótczesnej architektury sakralnej, Wrocław, Muzeum Architektury we Wrocławiu, 2008, ISBN 978-83 89262-45-5.

[14] Węcławowicz-Gyurkovich Ewa, Architektura najnowsza w historycznym środowisku miast europejskich, Kraków, Politechnika Krakowska im. Tadeusza Kościuszki, 2013, ISBN 977-83-7242-715-1. [15] Wierzbicka Anna Maria, Architektura jako narracja znaczeniowa, Warszawa, Oficyna Wydawnicza Politechniki Warszawskiej, 2013, ISBN 978-83-7814-136-5.
17 J. Gyurkovich, Architektura wczoraj, dziś, jutro - pomiedzy pięnem i oryginalnością, available at: https://suw.biblos.pk.edu.pl/ downloadResource\&mld=189832, retrieved on 03.04.2017.

18 M. Gyurkovich, Współczesne muzeum w strukturze miasta, Krakow 2007, p. 68-70.

${ }^{19}$ E. Węcławowicz-Gyurkovich, Architektura najnowsza w historycznym środowisku miast europejskich, Krakow 2013, p.179

${ }^{20}$ D. Libeskind, Przełom: Przygody w życiu i architekturze, Warsaw 2008 p. 48

21 ibid.

22 A.M. Wierzbicka, Architektura jako narracja znaczeniowa, Warsaw 2013, p. 118.

${ }^{23}$ A. Berleant, Wrażliwość i zmysty - estetyczna przemiana świata człowieka, Krakow 2010, p. 42

\section{BIBLIOGRAPHY:}

[1] Bartnicka Małgorzata, Magia cienia w zabawie z architekturą, Czasopismo Techniczne, 9-A, 2015, available online, 03.04.2017.

[2] Berleant Arnold, Wrażliwośd i zmysły - estetyczna przemiana świata człowieka, Krakow, Polskie Towarzystwo Estetyczne, 2010, ISBN 97883242-1663-5.

[3] Binet Hélène, Tajemnica cienia. Światło i cieo w architekturze, [in:] Co to jest architektura vol. 2; Krakow, Manggha, 2008, ISBN 978-83-924407-8-9. [4] Charciarek Marcin, Związki idei i materii w architekturze betonowej, Kraków, Politechnika Krakowska im. Tadeusza Kościuszki,2015, ISSN 0860-097X

[5] Feldhorn Juliusz, Dzieła i twórcy, popularny zarys historii sztuki, Warsaw, Wiedza Powszechna, 1961

[6] Gyurkovich Jacek, Architektura wczoraj, dziś, jutro - pomiedzy pięknem i oryginalnością, available at https://suw.biblos.pk.edu.pl/ downloadResource\&mld=189832, retrieved on 03.04.2017.

[7] Gyurkovich Mateusz, Wspótczesne muzeum w strukturze miasta, Kraków, Politechnika Krakowska im. Tadeusza Kościuszki, 2007, ISSN 0860 $-097 X$

[8] Le Corbusier, W strone architektury, Krakow, Centrum Architektury, 2012, ISBN 978-83-934574-9-6.

[9] Libeskind Daniel, Przełom: Przygody w życiu i architekturze, Warszawa, Wydawnictwo Naukowo-Techniczne, 2008, ISBN 978-83-204-3474-3.

[10] Pallasmaa Juhani, Oczy skóry - Architektura i zmysły, Kraków, Instytut architektury, 2012, ISBN 978-83-63786-01-4.

[11] Rassmussen Steen Eiler, Odczuwanie architektury, Warszawa, Wydawnictwo Murator, 1999, ISBN 83-904692-9-4.

[12] Stownik terminologiczny sztuk pieknych, under the editorship of Stefan Kozakiewicz, Warszawa, PWN, 1969.

[13] Wąs Cezary, Antynomie wspótczesnej architektury sakralnej, Wrocław, Muzeum Architektury we Wrocławiu, 2008, ISBN 978-83-89262-45-5.

[14] Węcławowicz-Gyurkovich Ewa, Architektura najnowsza w historycznym środowisku miast europejskich, Krakow Politechnika Krakowska im. Tadeusza Kościuszki, 2013, ISBN 977-83-7242-715-1.

[15] Wierzbicka Anna Maria, Architektura jako narracja znaczeniowa, Warsaw, Oficyna Wydawnicza Politechniki Warszawskiej, 2013, ISBN 978-837814-136-5. 